\title{
revistadechimie.ro
}

Vol. 72 / Number 3 / Year 2021
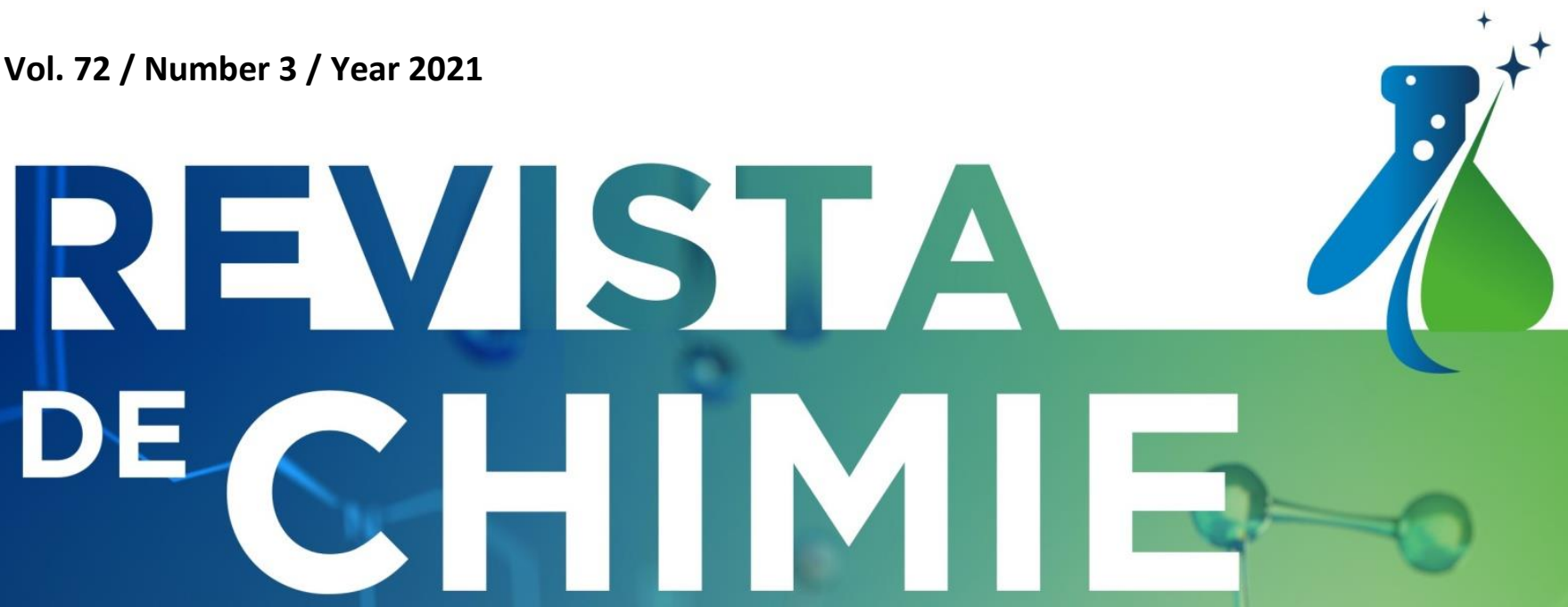

Chemistry Sciences

Chemical and Biochemical Engineering

Environmental Chemistry and Engineering

Chemistry Application in Food, Nutrition, Agriculture

Medical and Pharmaceutical Chemistry

Materials

\section{JULY 2021}


REVISTA DE CHIMIE FOUNDED IN 1949

BUCURESTI ROMANIA

EDITORIAL BOARD

Editor-in-Chief:

Gabriel Lucian RADU

Politehnica University of Bucharest, Romania

Editorial Manager:

Ion ANDRONACHE

Revista de Chimie SRL, Bucharest, Romania

\section{EDITORS:}

Ionel MANGALAGIU - Chemistry Sciences

Alexandru Ioan Cuza University, Iasi, Romania

Irinel Adriana BADEA - Chemistry Sciences University of Bucharest, Romania

Costin Sorin BILDEA - Chemical and Biochemical Engineering

Politehnica University of Bucharest, Romania

Ioana FECHETE - Chemical and Biochemical Engineering Université de Technologie de Troyes, France

Gheorghe NECHIFOR - Environmental Chemistry and Engineering Politehnica University of Bucharest, Romania

Simona Gabriela BUNGAU - Environmental Chemistry and Engineering University of Oradea, Romania

Adela PINTEA - Chemistry Application in Food, Nutrition, Agriculture University of Agricultural Sciences and Veterinary Medicine Cluj-Napoca, Romania

Gabriela RAPEANU - Chemistry Application in Food, Nutrition, Agriculture Dunarea de Jos University of Galati, Romania

Gabriel Ovidiu BRATU - Medical and Pharmaceutical Chemistry

Carol Davila University of Medicine and Pharmacy, Bucharest, Romania

Camelia DIACONU - Medical and Pharmaceutical Chemistry

Carol Davila University of Medicine and Pharmacy, Bucharest, Romania

Maria CAZACU - Materials

Petru Poni Institute of Macromolecular Chemistry, Iasi, Romania

Iulian ANTONIAC - Materials

Politehnica University of Bucharest, Romania 
ASOCIATE EDITORS:

Lotfi ALEYA

Université de Franche-Comté, France

Patrick Da COSTA

Sorbonne Universite, France

Remi CHAUVIN

University of Toulouse, France

Huaqiao University, Xiamen Campus, China

Giuseppe GATTUSO

University of Messina, Italy

Andrei JITIANU

Lehman College of The City University of New York, USA

Piotr KURCOK

Centre of Polymer and Carbon Materials Polish Academy of Sciences, Poland

Bouchta SAHRAOUI

University of Angers, UFR Sciences

Institute of Sciences and Molecular Technologies of Angers, France

Yanzhong ZHANG

College of Chemistry, Chemical Engineering \& Biotechnology Donghua University, China

\section{EDITORIAL ADVISORY BOARD:}

\section{Sanda ANDREI}

University of Agricultural Sciences and Veterinary Medicine, Cluj-Napoca, Romania

Narcis BARSAN

Vasile Alecsandri University of Bacau, Romania

\section{Ede BODOKI}

Iuliu Hatieganu University of Medicine \& Pharmacy, Cluj-Napoca, Romania

Andreea BUNEA

University of Agricultural Sciences and Veterinary Medicine, Cluj-Napoca, Romania

Ioan CALINESCU

Politehnica University of Bucharest, Romania

Simona CAPRARESCU

Politehnica University of Bucharest, Romania

Otilia CINTEZA

University of Bucharest, Romania

Simona CLICHICI

University of Medicine and Pharmacy, Cluj-Napoca, Romania

Carolina CONSTANTIN

Victor Babes National Institute, Bucharest, Romania

Lucian Octav COPOLOVICI

Aurel Vlaicu University, Arad, Romania 


\section{Calin Cristian CORMOS}

Babeş-Bolyai University, Cluj Napoca, Romania

\section{Dana CULITA}

Institute of Physical Chemistry Ilie Murgulescu, Bucharest, Romania

Andrei DANET

University of Bucharest, Romania

Iulia Gabriela DAVID

University of Bucharest, Romania

\section{Gyorgy DEAK}

INCDPM, Bucharest, Romania

Kamel EARAR

Dunarea de Jos University of Galati, Romania

Petru FILIP

C. D. Nenitescu Institute of Organic Chemistry, Bucharest, Romania

\section{Anca Irina GALACTION}

University of Medicine and Pharmacy Grigore T. Popa, Iasi, Romania

Maria HARJA

Tehnical University Gheorghe Asachi, Iasi, Romania

\section{Cosmin JINESCU}

Politehnica University of Bucharest, Romania

Vasile LAVRIC

Politehnica University of Bucharest, Romania

\section{Simona Carmen LITESCU}

National Institute for Biological Sciences, Bucharest, Romania

\section{Cristian MATEI}

Politehnica University of Bucharest, Romania

\section{Florin MICULESCU}

Politehnica University of Bucharest, Romania

Maria MOHORA

Carol Davila University of Medicine and Pharmacy, Bucharest, Romania

Lucia MUTIHAC

University of Bucharest, Romania

Denisa NISTOR

Vasile Alecsandri University of Bacau, Romania

\section{Octavian OLARU}

Carol Davila University of Medicine and Pharmacy, Bucharest, Romania

Eliza OPREA

University of Bucharest, Romania

\section{Ovidiu OPREA}

Politehnica University of Bucharest, Romania 
Cristian Valeriu PIRVU

Politehnica University of Bucharest, Romania

Ileana RAU

Politehnica University of Bucharest, Romania

Sonia SOCACI

University of Agricultural Sciences and Veterinary Medicine, Cluj-Napoca, Romania

Bogdan SOCEA

Carol Davila University of Medicine and Pharmacy, Bucharest, Romania

Irina STOIAN

Carol Davila University of Medicine and Pharmacy, Bucharest, Romania

Emanuel VAMANU

University of Agronomical Sciences and Veterinary Medicine, Bucharest, Romania

Camelia VIZIREANU

Dunarea de Jos University of Galati, Romania

Laurian VLASE

University of Medicine and Pharmacy Iuliu Hatieganu, Cluj Napoca, Romania

Maria ZAHARESCU

Institute of Physical Chemistry Ilie Murgulescu, Bucharest, Romania

Romanian Academy

PUBLISHER STAFF:

Alice CRISTEA - Manager

Elena ANDRONACHE - IT

Monica BALUTA - Editing

Iuliana GHITA - Accounting

Impact factor 2019: 1.755 


\section{CONTENTS}

$3 / 2021$

\section{CRISTINEL CONSTANDACHE, LUCIAN CONSTANTIN DINCA, CIPRIAN TUDOR}

The Chemical Properties of Soils from Forest Fields Occupied by Oil Drills in Moinesti, Romania .1

FAIZA KHOUKHI, NACER-EDDINE DJELALI, SALIMA KEBOUCHE, MOHAMED LAMINE GANA Contribution to the Study of Biotechnological Control Techniques Applied Against Biocorrosion Oil Installations

FEI WU, HAIGANG LI, CHEN CHENG, HAO ZHANG, SHUNXIN FEI

Synergistic Effect of FeNi Bimetallic Clusters for the Catalytic of Hydrogen Dissociation and Desorption:

A Density Functional Theory Study....

HAIFENG TIAN, YONGYONG NAN, JINLONG LV, FEI ZHA, XIAOHUA TANG,

YUE CHANG, XIAOJUN GUO

Catalytic Performance of Phosphorus Incorporated HZSM-5 in Coupling Transformation of

Methanol with 1-butene to Propylene.

LEI GONG, JIN WANG, HONG WEI YU, YING ZHOU, TONG ZOU,

\section{HAO NAN ZHANG, JUN ZHOU}

The Effect of Temperature and Particle Size on the Pyrolysis Products of Waste Tires and the Formation Mechanism of Limonene.

SHANMUGAM PALANISAMY

Hydrodenitrogenation of 2-methyl Quinoline - Effect of Steric Hindrance

in Liquid Phase Catalytic Hydrogenation.

FARZANA SHAHEEN, ZAFAR IQBAL KHAN, TASNEEM AHMAD, MUHAMMAD YASEEN ASHRAF,

KAFEEL AHMED, SONAINA NAZAR, MUHAMMAD NADEEM, SHAHID MEHMOOD, MUHAMMAD UMER FAROOQ AWAN, MONA S ALWAHIBI, MOHAMED SOLIMAN ELSHIKH, MOHAMED RAGAB ABDELGAWWAD

Screening of Wheat (Triticum aestivum L.) Genotypes for Salt Tolerance on the Basis of

Physiochemical Characteristics and Bio-Physiological Parameters and Indices

ZHIPING SUN, YUQIAO WAN, CHUNLAN JIANG, CHENGMEI GUI

A Facile Method Combined with Acetic Acid Modification and Electroless Plating to Fabricate

Copper-plated Nylon 12 Powder for Antistatic Coating.

GUOWEI ZENG, GUIHONG WU, ZHIHUI WANG, XIAONAN LI, JIE YANG, HONG ZHANG

Immobilization of $\mathrm{K}_{7} \mathrm{PW}_{11} \mathrm{O}_{39}$ on $\mathrm{ZrO}_{2}$ Nanofiber: Ultra-deep Desulfurization Based in Extraction

Catalytic Oxidation Desulfurization System.

JAMAL STAS, MARWA YOUSEF

Extraction of Lactic Acid from Whey of Yoghurt by Solvent Extraction Technique

IRUM BASHIR, MUHAMMAD UMER FAROOQ AWAN, SOHAIB MUHAMMAD, ANDLEEB ANWAR SARDAR, MUHAMMAD LUQMAN, FARIHA AROOJ

Physiochemical Alterations and Air Pollution Tolerance Index in Ficus religiosa L. Planted

Along Polluted Roadsides of Lahore City

KANG LI, MIN ZHENG, JINGQUAN WANG, JUN WU

Reduction Characteristic of $\mathrm{CaSO}_{4}-\mathrm{CuO}$ Combined Oxygen Carrier Under $\mathrm{CO}$ Atmosphere

ARRIETA ALVARO, ISORA BARRERA, JORGE MENDOZA

Polyaniline as Additive to Improve the Anticorrosive Properties of Commercial Paint....

KAVITHA KAMALASEKARAN

Potentiometric Titration of Vanadium (V) with Iron (II) in the Presence of NTA and DTPA

Using Dry-Cell Graphite Electrode. 
SARKAR MOHAMMAD ABE KAWSAR, MOHAMMED ANOWAR HOSEN,

TASNEEM SULTANA CHOWDHURY, KAZI MASUD RANA, YUKI FUJII, YASUHIRO OZEKI

Thermochemical, PASS, Molecular Docking, Drug-Likeness and In Silico ADMET Prediction of

Cytidine Derivatives against HIV-1 Reverse Transcriptase...

FATMA. M. ABOUZEID

Study of Steel Electro-dissolution Behavior in Presence of Some Surfactants. Electrochemical Investigation

and Surface Active Properties Determination

YUNITA ANGGRAINI, INGE MAGDALENA SUTJAHJA

Analysis of Biphenylene and Benzo $\{3,4\}$ cyclobuta $\{1,2-c\}$ thiophene Molecular Orbital

Structure using the Hückel Method. 